\title{
Domestication Effects on the Stress Response in Chickens \\ Genetics, Physiology, and Behaviour
}

Amir Fallahshahroudi

IFM Biology

Department of Physics, Chemistry and Biology

Linköpings University

SE-581 83 Linköping, Sweden 
Domestication Effects on the Stress Response in Chickens:

Genetics, Physiology, and Behaviour

Linköping Studies in Science and Technology

Dissertation No. 1842

ISBN: 978-91-7685-546-1

ISSN: 0345-7524

Cover Artist: Behzad Shishegaran

Copyright Amir Fallahshahroudi

Printed by LiU-Tryck, Linköping, Sweden, 2017 


\section{ABSTRACT}

Animal domestication, the process where animals become adapted to living in proximity to humans, is associated with the alteration of multiple traits, including decreased fearfulness and stress response. With an estimated population of 50 billion, the domesticated chicken is the most populous avian species in the world. Hundreds of chicken breeds have been developed for meat and egg production, hobby or research purposes. Multidirectional selection and the relaxation of natural selection in captivity have created immense phenotypic diversity amongst domesticates in a relatively short evolutionary time. The extensive phenotypic diversity, existence of the wild ancestor, and feasibility of intercrossing various breeds makes the chicken a suitable model animal for deciphering genetic determinants of complex traits such as stress response. We used chicken domestication as a model to gain insights about the mechanisms that regulate stress response in an avian species. We studied behavioural and physiological stress response in the ancestral Red Junglefowl and one of its domesticated progenies, White Leghorn. An advanced intercross between the aforementioned breeds was later used to map genetic loci underlying modification of stress response. The general pattern of the stress response in chickens was comparable with that reported in mammals, however we identified distinctive differences in the stress modulatory pathways in chickens. We showed that changes in the expression levels of several stress modulatory genes in the brain, the pituitary and the adrenal glands underlie the observed modified stress response in domesticated chickens. Using quantitative trait loci (QTL) mapping, several QTL underlying stress induced corticosterone, aldosterone and baseline dehydroepiandrosterone (DHEA) levels were detected. As a next step, we combined QTL mapping with gene expression (eQTL) mapping and narrowed two QTL down to the putative causal genes, SERPINA10 and PDE1C. Both of these genes were differentially expressed in the adrenal glands of White Leghorn and the Red Junglefowl, had overlapping eQTL with hormonal QTL, and their expression levels in the adrenal glands were correlated with plasma levels of corticosterone and aldosterone. These two genes thus serve as strong candidates for further functional investigation concerning modification of the stress response during domestication. This dissertation increase the knowledge about genetics and physiology of the stress response in an avian species and its modification during domestication. Our findings expand the basic knowledge about the stress response in chicken, which can potentially be used to improve welfare through appropriate genetic selection.

Keywords: animal domestication, stress response, gene expression, QTL, eQTL 


\section{Populärvetenskaplig sammanfattning}

Domesticeringen av djur, alltså processen där djur anpassats för att leva i människans närhet, går hand $\mathrm{i}$ hand med ändringar av många olika egenskaper, bland annat en lägre rädsla och en lägre stressnivå. Domesticerade höns är en av de vanligaste fåglarna och det finns mer än 50 miljarder höns i världen uppdelade på olika raser. Hundratals hönsraser har utvecklats för kött- och äggproduktion men också av hobbyskäl och för forskning. På grund av olika mål med avelsarbetet har det lett till att det finns en stor variation bland höns både i utseende och beteende. Gener och reaktionsvägar som är involverade i stressresponsen är välstuderade hos däggdjur medan det inte finns lika mycket kunskap om hur det fungerar hos fåglar. Höns är ett lämpligt modelldjur för att studera den genetiska grunden till ett så pass komplext system som stressresponsen på grund av att det finns en stor variation bland hönsen, att deras vilda förfader fortfarande finns och att det är möjligt att korsavla raser. För att få en större kunskap om de mekanismer som styr stressresponsen hos fåglar har vi därför använt höns som modell. Vi har studerat både beteendereaktioner och fysiologiska reaktioner på stress hos dels den ursprungliga röda djungelhönan och dels den domesticerade rasen white leghorn. Dessa två har även korsavlats för att möjliggöra en kartläggning av gener som ligger till grund för de förändringar av stressresponsen som skett under domesticeringen. Det vi hittade var att det generella mönstret $\mathrm{i}$ stressresponsen hos höns är likt det som rapporterats hos däggdjur men vi hittade också tydliga skillnader. Vi visade även att skillnader $\mathrm{i}$ genernas expressionsnivåer i hjärnan, hypofysen och binjurarna ligger bakom de skillnader som finns mellan i stressresponsen mellan djungelhönsen och de domesticerade hönsen. Dessutom identifierade vi två genregioner som tycks ansvara för skillnaderna. Genom att kombinera kartläggning av hormoner med kartläggning av genexpression kunde dessa två regioner skäras ner till två förmodade ansvariga gener, SERPINA10 och PDE1C. Vi kunde även se att expressionsnivåerna av dessa gener skiljer mellan den röda djungelhönan och white leghorn och dessutom att expressionsnivåerna korrelerar med plasmanivåer av kortikosteron och aldosteron. Den här avhandlingen ger en ökad kunskap om genetiken och fysiologin bakom stressresponsen hos fåglar och ger även en ökad kunskap om förändringar som skett under hönsets domesticering. I och med att våra resultat ökar den grundläggande förståelsen för fåglars stressfysiologi kan de också potentiellt användas för att öka djurvälfärden hos höns genom avelsprogram. 


\section{List of publications:}

Maria Ericsson, Amir Fallahsharoudi*, Jonas Bergquist, Mark M Kushnir, Per Jensen: Domestication effects on behavioural and hormonal responses to acute stress in chickens. Physiology \& Behavior 05/2014; 133: 161-169.

Amir Fallahsharoudi, Neil de Kock, Martin Johnsson, S. J. Kumari A. Ubhayasekera, Jonas Bergquist, Dominic Wright, Per Jensen: Domestication Effects on Stress Induced Steroid Secretion and Adrenal Gene Expression in Chickens. Scientific Reports 10/2015; 5:15345.

Amir Fallahsharoudi, Neil de Kock, Martin Johnsson, Lejla Bektic, S J Kumari A Ubhayasekera, Jonas Bergquist, Dominic Wright, Per Jensen: Genetic and Targeted eQTL Mapping Reveals Strong Candidate Genes Modulating the Stress Response During Chicken Domestication. G3-Genes Genomes Genetics 12/2016; $7(2)$.

Amir Fallahsharoudi, Neil de Kock, Martin Johnsson, Lejla Bektic, S.J. Kumari A. Ubhayasekera, Jonas Bergquist, Dominic Wright, Per Jensen: QTL mapping of stress related gene expression in a cross between domesticated chickens and ancestral red junglefowl. Molecular and Cellular Endocrinology 02/2017; 446:52-58.

Pia Løtvedt, Amir Fallahsharoudi*, Lejla Bektic, Jordi Altimiras, Per Jensen, Chicken domestication changes expression of stress related genes in brain, pituitary and adrenals. Submitted Manuscript.

* Equal contribution

\section{Publications not included in the thesis:}

Anna-Carin Karlsson, Amir Fallahshahroudi, Hanna Johnsen, Jenny Hagenblad, Dominic Wright, Leif Andersson, Per Jensen: A domestication related mutation in the thyroid stimulating hormone receptor gene (TSHR) modulates photoperiodic response and reproduction in chickens. General and Comparative Endocrinology 02/2016; 228: 69-78.

Magnus Elfwing, Amir Fallahshahroudi, Isa Lindgren, Per Jensen, Jordi Altimiras: The Strong Selective Sweep Candidate Gene ADRA2C Does Not Explain Domestication Related Changes in the Stress Response of Chickens. PLoS ONE 08/2014; 9(8): e103218. 


\section{Table of Contents}

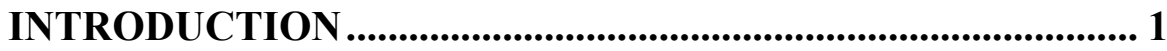

Domestication ............................................................................................................... 1

Domestication of chicken ............................................................................. 2

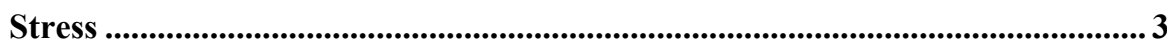

Physiology of the stress response ............................................................................... 4

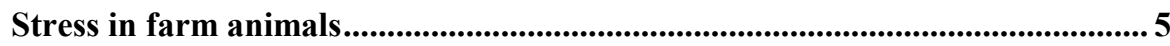

Mapping genes underlying domestication traits...................................................... 6

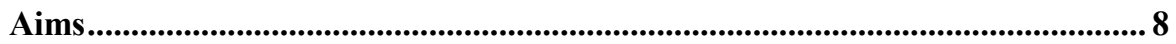

ANIMALS AND METHODS ..................................................... 9

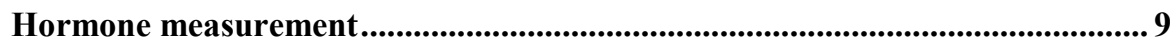

Gene expression .................................................................................................. 10

PAPER SUMMARIES ......................................................... 11

Paper I............................................................................................................. 12

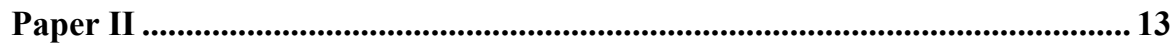

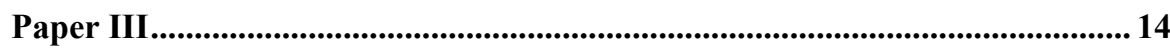

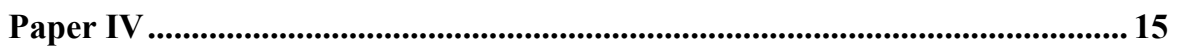

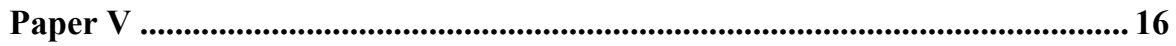

DISCUSSION ........................................................................ 17

Effects of domestication on the behaviour and physiology ................................... 17

Effects of domestication on gene expression ......................................................... 18

Quantitative trait mapping........................................................................................... 20

CONCLUSION ................................................................. 22

ACKNOWLEDGEMENT ........................................................ 23

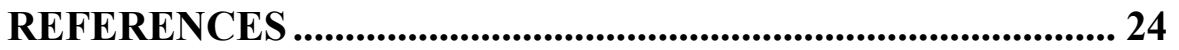




\section{Introduction}

\section{Domestication}

Domestication of plants and animals was a major prerequisite to the rise of human civilizations. Besides food, domesticated animals provided early farmers with fertilizer, wool and leather, plow traction, facilitated transportation, and help in wars (Diamond, 2002). Domesticates are different from their wild counterparts due to genetic modifications caused by generations of living in captivity (Price, 1999). Only a very small proportion of seemingly domesticable animals have successfully undergone domestication. Diamond suggested a list of traits that are prerequisite to a successful domestication event (Diamond, 2002). These traits include having an omnivorous diet, fast growth rate, being able to reproduce in captivity, living in a social group, not being too aggressive, and having a low fearfulness. Darwin mentioned the extensive phenotype diversity amongst the domestic animals as an example of natural selection. He realized that domesticated animals exhibit a set of shared behavioural and morphological characteristics which are not seen in their wild counterparts (Darwin, 1868). Today these traits include changes in the coat colour, relaxed seasonal reproduction, prolongations in juvenile behaviour, changes in the brain size and increased docility and tameness (Wilkins et al., 2014).

Being tame and docile is a universal trait amongst all studied domesticates (Price, 1999; Price, 2002). Lowered fearfulness and tendency to panic allow the individuals to tolerate human proximity and to live in a more crowded and confined environment (Price, 1999). The lowered fearfulness in the domesticates is accompanied by the hampered physiological stress response in all studied domesticates (Treidman and Levine, 1969; Drew et al., 2007; Albert et al., 2008; Trut et al., 2009; Soleimani et al., 2011; Ericsson et al., 2014). Attenuation of behavioural and physiological stress response in the domesticates is suggested to be caused by the direct or indirect selection for tameness and the relaxation of natural selection in captivity (Rauw et al., 1998; Schütz et al., 2004). It is worth noting that selection 
solely for tameness has been sufficient to trigger attenuated HPA axis reactivity in fox and rat (Gulevich et al., 2004; Albert et al., 2008). Domesticated animals and plants have been used extensively as a model for studying evolution. Genomic research in domesticated animals has contributed to the welfare of animals, as well as model for understanding the genetics determinants of phenotypic variation (Andersson, 2012).

\section{Domestication of chicken}

Chicken domestication happened about 8000 years ago in Asia (TixierBoichard et al., 2011; Xiang et al., 2014). Darwin mentioned the Red Junglefowl as the closest ancestor to the domesticated chicken (Darwin, 1868). His view was later confirmed by the analysis of mitochondrial DNA (Fumihito et al., 1994). Most of the chicken's genome, including its mitochondrial DNA, originates from the Red Junglefowl, however hybridization between Grey Junglefowl and the domesticated chicken has also contributed to the chicken genome (Eriksson et al., 2008). The chicken is the most numerous domesticated species and hundreds of chicken breeds have been developed for meat and egg production, hobby, or research purposes (Crawford, 1990). Multidirectional selection by the humans combined with the relaxation of natural selection in captivity have created a broad phenotypic diversity amongst chicken breeds (Rubin et al., 2010). In general, domestic chickens have a higher growth rate, become sexually mature earlier, lay more and bigger eggs and show lower fearfulness relative to the ancestral Red Junglefowl (Price, 1999; Kerje et al., 2003; Schütz et al., 2004; Campler et al., 2009; Wright et al., 2010; Wright et al., 2012b). Extensive phenotypic diversity among chicken breeds, possibility of crossing different breeds, and existence of the ancestral species, make chicken a desirable model animal for gene mapping of complex traits. Owing to the experimental advantages of in ovo embryogenesis, the chicken has been used as the historical model in studying embryogenesis and developmental biology in vertebrates (Mueller et al., 2015). Avian genomes have evolved in parallel to mammalian genomes for more than 300 million years, and this evolutionary distance has been 
used for improving gene annotations as well as discovering functional elements in human genome (Hillier et al., 2004).

\section{Stress}

Modification of the stress response is widespread amongst domesticated animals. The endocrine system plays a key role combining external and internal stimuli and organizing adequate responses intended to maximizing fitness (Blas, 2015). Historic definitions of stress are focusing on physiological or behavioural outcomes of stress rather than its underlying causes (Moberg, 2013). Hans Selye first introduced the idea of a general adaptation syndrome and defined stress as the nonspecific response of body to any demand (Selye, 1973). General adaptation syndrome is divided into alarm reaction, resistance, and exhaustion. The alarm reaction to a harmful stimuli includes the activation of HPA axis. The continuous exposure to the stimuli would lead to physiological resistance and eventually exhaustion of body resources and death. The more modern definitions of stress are trying to incorporate the homeostasis in the context of individual differences and life history (Blas, 2015). The process of maintaining the stability of the vital physiological systems (homeostasis) through changes is defined as allostasis. The allostasis model emphases on the balance between the energy input and energy expenditure to predict the outcome of the threats to the homeostasis (McEwen and Wingfield, 2003). The reactive scope model combines the allostasis model with the traditional model of stress (Romero et al., 2009).

Throughout this dissertation, the term "stress" means the state of real or interpreted threat to the physiological or psychological integrity of an individual (McEwen, 2000; Koolhaas et al., 2011). Stress triggers activation of a complex range of physiological and behavioural responses that are together known as the stress response (Arnetz and Ekman, 2006; Chrousos, 2009; Koolhaas et al., 2011). The stress response is adaptive and vital, enabling the organisms to adjust their behaviour and physiology to cope with the potential threats (Korte et al., 2005). On the other hand, the stress response is costly and can be damaging if it is triggered 
too often or over a long time (De Kloet et al., 2005). Throughout this dissertation, we used handling and restraint as the stressor. Capturing and restraining the animals is a well-studied physical stressor and leads to increase in the plasma levels of glucocorticoids in the blood (Paré and Glavin, 1986; Buynitsky and Mostofsky, 2009). Glucocorticoids are important hormonal mediators of the stress and reflect how the individual responds to the imposed challenges.

\section{Physiology of the stress response}

The stress response is complex, and several modulatory pathways work in parallel to maintain homeostasis during threat. The sympathoadrenal (SA) system and the hypothalamic-pituitary-adrenal (HPA) axis are the main regulators of the stress response. Adrenalin and glucocorticoids are the main hormones released by the activation of the SA system and the HPA axis respectively (Blas, 2015). Specific neurons in the paraventricular nucleus of the hypothalamus secrete corticotropin-releasing hormone $(\mathrm{CRH})$ as well as other peptide hormones, like arginine vasopressin (AVP), into the hypophysial portal plexus of veins after exposure to stressors. The veins transport CRH and AVP into the anterior lobe of the pituitary gland, where they bind to their designated receptors, leading to production and release of adrenocorticotropic hormone (ACTH) into the blood circulation (Herman et al., 2016). Melanocortin Receptor Type 2 (MC2R) in the adrenal cortex is the main target of ACTH. The first and rate-limiting step of steroidogenesis in response to $\mathrm{ACTH}$ is the transportation of cholesterol into the intermembrane space of the mitochondria by the Steroidogenic Acute Regulatory (StAR) proteins family (Lin et al., 1995; Stocco, 2001). Cytochrome P450 family 11 subfamily A member 1 (CYP11A1) and 3 Beta-Hydroxysteroid Dehydrogenase Type 2 (HSD3B2) catalyze the steps between cholesterol and various steroids which are then released into the blood (Xing et al., 2010). Activation of the SA system happens in parallel to the HPA axis response. During stress periods, adrenalin is synthetized and released by the adrenal chromaffin cells. Several enzymes including tyrosine hydroxylase (TH), 
dopamine beta-hydroxylase (DBH), and phenylethanolamine N-methyltransferase (PNMT) convert tyrosine to adrenalin (Carsia, 2015).

Stress hormones have a broad range of effects depending on the target tissue, but the overall function is to alter resource allocation to promote immediate survival, while suppressing body functions that are not crucial for immediate survival (Herman et al., 2016). Behavioural aspects of the stress include increased vigilance, suppression of feeding, and enhanced cognition. Activation of the stress system leads to increased cardiovascular tone, respiratory rate and metabolism. The stress has inhibitory effects on general vegetative functions such as growth, immunity, digestion, and reproduction (Sapolsky et al., 2000; Wingfield and Sapolsky, 2003).

\section{Stress in farm animals}

Chronic exposure to stress hormones is energetically costly and is associated with a number of physical diseases such as cardiovascular diseases, obesity, and diabetes as well as wide range psychological problems in humans and animals (Herman et al., 2016). Domesticated animals live in a captive environment that is less stimulating and more densely populated compared to the wild. Captive animals are not able to perform many of their natural behaviours, which is considered to be frustrating and a source of stress (Price, 2002; Clubb and Mason, 2003; Jensen, 2010). Stress in captivity contributes to the development of abnormal behaviours such as feather pecking, tail biting, stereotypic pacing, disruption of reproduction, and high prevalence of infectious diseases in domesticated animals (Broom, 1983). Inability of pigs and cattle to perform their natural behaviours such as grazing and foraging is associated with development of stress related behavioural and physiological abnormalities such as tail biting in pigs and non-nutritional suckling in calves (reviewed by Rauw et al., 1998). Besides the environmental factors, artificial selection for high production efficacy has caused numerous negative side effects in farm animals. For example, modern turkeys and broiler chicken are too heavy to mate without causing serious injuries to the back of females (Rauw et al., 1998). 
Broiler chickens have a low antibody response when they are exposed to a neutral antigen and they have a higher mortality rate during various epidemics (Qureshi and Havenstein, 1994). Genetic disposition and environmental factors determine the vulnerability to develop stress related diseases in humans and animals (Arnetz and Ekman, 2006). Selection for higher stress resilience has been suggested to improve the welfare of domesticated animals (Mormede et al., 2011; Mormède et al., 2011).

\section{Mapping genes underlying domestication traits}

Several methods have been used for deciphering the genetic basis of the modified traits during animal domestication. Quantitative trait locus (QTL) mapping is a genetic mapping method used to link genotype to phenotypic data, aiming to explain the genetic basis of variation in complex traits (Mackay, 2001). Two genetically divergent lines for the trait of interest are crossed to produce $F_{1}$, in which individuals are heterozygous for all genetic loci. $F_{1}$ animals are then intercrossed in order to create $F_{2}$. The genotype and phenotype of each of these individuals are measured for QTL mapping. Markers that are genetically linked to a QTL that affect the phenotype will segregate more often with phenotype (for example high or low corticosterone), and the markers that are not linked with the QTL will not show significant association with the phenotype (Flint and Mott, 2001; Mackay, 2001). Confidence intervals of QTL are usually large and can contain tens or hundreds of genes in $F_{2}$ intercrosses. Breeding the $F_{2}$ individuals for many generations (advanced intercrossing) leads to accumulation of recombination events, allowing genetic mapping with finer resolution (Darvasi and Soller, 1995). Combining QTL mapping with gene expression (eQTL) can be used to narrow down QTL regions to their potentially causative genes. The idea of eQTL mapping is to find DNA variation that affects phenotype by modifying gene expression (Kendziorski and Wang, 2006). Co-localization of QTL and eQTL combined with correlation between gene expression and the phenotype suggest that the candidate gene may cause the QTL (Doss et al., 2005). 
Genetic determinants of hundreds of quantitative traits have been successfully mapped to the causing loci or genes in domesticated animals. For instance, mutations at Melanocortin Receptor 1 (MC1R), have been associated with distribution of black pigments in several domesticates including pigs, chickens, dogs, horse, and sheep (reviewed by Andersson, 2001; Andersson, 2012). QTL underlying higher growth rate and fertility in pigs are mapped to the causal genes (Andersson and Georges, 2004). In dog breeds, mutations underlying skeletal morphology, growth, coat color, fur texture, and adaptation to new diets are identified (Cadieu et al., 2009; Shearin and Ostrander, 2010; Axelsson et al., 2013). Genes or loci underlying growth, egg production, bone strength, comb size, and behaviour have been previously identified in a cross between the domesticated White Leghorn and the ancestral Red Junglefowl (Schütz et al., 2002a; Schütz et al., 2002b; Abasht et al., 2006; Rubin et al., 2007; Wright et al., 2012a).

Besides morphological traits, a number of behavioural and physiological traits such as fearfulness and stress response have also been modified during animal domestication (Price, 1999; Schütz et al., 2001; Jensen, 2010). Intercrosses between the traditional or experimental domesticated animals with their wild counterparts have been used to link genome with behaviour and physiology (Jensen and Andersson, 2005). The SERPINA6 gene, that codes for corticosteroid binding globulin $(\mathrm{CBG})$, has been suggested to be underlying the QTL with largest effect on the stress response in a cross between two breeds of pigs with high and low corticosterone response (Désautés et al., 2002; Ousova et al., 2004). In a cross between two rat strains with high and low HPA axis reactivity (Solberg et al., 2006) showed that different aspect of HPA axis is regulated by multiple non overlapping QTL. In mice, a large number of studies have reported genetic loci underlying behavioural traits that influence susceptibility to anxiety and depression (Flint and Mott, 2001; Bucan and Abel, 2002; Hovatta and Barlow, 2008; Feder et al., 2009). Behavioural QTL usually have a small effect on the phenotype and hence identification of the causal gene is very challenging (Yalcin et al., 2004). The genetic determinants of fearfulness has been studied using rat and silver foxes which were selected for high or low fear of human (Trut et al., 2009; Kukekova et al., 2011). 
Using an advanced intercross between domesticated chicken and the ancestral Red Jungle fowl, Johnsson et al. (2016) suggested potential genes underlying anxietylike behaviour in chicken. Keeling et al. (2004) showed that the PMEL17 gene, that regulates feather pigmentation, is associated with feather pecking, a welfare issue in domesticated chickens.

Mutations at regulatory elements play a crucial role in modulation of gene expression. Variation in gene expression underlies the majority of behavioural, physiological, and morphological differences between closely related species (Wray, 2007; Necsulea and Kaessmann, 2014). Brain transcriptomes of several domesticated species have been compared with their wild type ancestor. Comparison data showed that causative variants underlying behavioural traits are specific to each domestication event (Albert and Kruglyak, 2015). Nätt et al. (2012) showed that in the hypothalamus, expression levels of more than 280 genes were different between domesticated White Leghorn and the Red Junglefowl.

\begin{abstract}
Aims
Domesticated animals generally have hampered behavioural and physiological stress responses. However, the knowledge about the genetic basis of the lowered stress response in domesticates is limited. The aim of this thesis was to gain a better understanding about the genetics and physiology of the stress response in the chicken and its modification during domestication. We compared the behavioural and the physiological stress response of the domesticated White Leghorn with its progenitor, the Red Junglefowl. At the next step, we used gene expression analysis, QTL and eQTL mapping to identify the genes and pathways that regulate domestication related modification of the stress response in chicken.
\end{abstract}




\section{Animals and methods}

We studied the effects of domestication on behaviour, physiology, and gene expression levels by comparing one population of Red Junglefowl and one population of domesticated White Leghorn (Paper I \& II \& III). For QTL and targeted eQTL analysis (Paper IV\& V), we used the $12^{\text {th }}$ generation of the advanced intercross between the aforementioned populations. The Red Junglefowl population in this thesis originates from a zoo population that was wild caught from Thailand, and maintained in our research facilities for about 15 generations. The White Leghorn strain, SLU13, originates from an outbred strain for research purposes, later selected for egg mass, but does not represent any commercial strain of birds. (Schütz et al. 2002; Wright et al. 2006). The advanced intercross consisted of the $12^{\text {th }}$ generation between the White Leghorn and Red Junglefowl. The intercross was generated by pairing one Red Junglefowl male and three White Leghorn females to obtain $41 \mathrm{~F}_{1}$ and then $821 \mathrm{~F}_{2}$ animals. The successive generations were retained at population sizes of more than 100 chickens per generation.

\section{Hormone measurement}

In order to study hormonal stress response concerning animal domestication, we measured plasma levels of several steroid (Paper I, II, IV, and V) using liquid chromatography-tandem mass spectrometry (LC-MS/MS). Liquid chromatography (LC) separates the sample components and then introduces them to the mass spectrometer (MS). The MS creates and detects charged ions. The main advantage of is that several steroid hormones can be measured simultaneously with high specificity and sensitivity (Jemal, 2000). 


\section{Gene expression}

Messenger RNA (mRNA) is an intermediate molecule between DNA and protein, and its levels are a valid indicator of protein levels in eukaryote cells (Darnell et al., 1990). In paper I, III, IV, and V, we used real time polymerase chain reaction (RT-PCR) and used microarrays in Paper II. RT-PCR is one of the most commonly used methods of gene quantitation and allows relative quantification of gene(s) of interest with high sensitivity. In microarrays, gene-specific polynucleotides are individually arrayed on a single matrix. This array later is hybridized by labeled cDNA, which is derived from RNA in the samples. Gene expression patterns of tens of thousands of genes can be measured in a single experiment using cDNA microarrays (Schulze and Downward, 2001). 
Paper Summaries 


\section{Paper I}

Aims and methods

The aim of the study was to assess the effects of stress and domestication on chicken behaviour and physiology. We compared the behavioural and physiological stress responses of mature domesticated White Leghorn and the ancestral Red Junglefowl. After a habituation period the baseline behavioural patterns were recorded. The birds were then captured, restrained for a short time, then released and video recorded for an additional hour to measure behaviour. We also took blood samples at several time points to measure plasma levels of sex and stress hormones.

\section{Results and conclusion}

Compared to the White Leghorn, the Red Junglefowl showed a more pronounced behavioural stress response, and they resumed their natural behaviour after a shorter time. Corticosterone levels increased after restraint in both breeds, and this increase was significantly more pronounced in the Red Junglefowl. The Red Junglefowl showed a complete recovery one hour after the restraint while White Leghorn did not have a full recovery to baseline during that time. Baseline levels of several hormones that are mainly related to reproduction were higher in White Leghorn. The effects of stress on a range of steroid hormones was more pronounced in the White Leghorn compared with the ancestral Red Junglefowl. The acute stress response and fast recovery may be adaptive under natural conditions, whereas the stress response and recovery of domesticated birds has been changed by domestication. 


\section{Paper II}

\section{Aims and methods}

The aim of the study was to investigate the molecular basis for the altered physiological stress responsiveness in the juvenile domesticated chicken. We investigated the effects of stress on the transcriptome in the adrenal glands of White Leghorn and Red Junglefowl. For measuring mRNA levels in the adrenal glands, we used microarray analysis and RT-PCR. Using HPLC-MS/MS we also measured corticosterone, pregnenolone, and DHEA to repeat our previous findings in the adult birds.

\section{Results and conclusion}

Similar to the mature birds, Red Junglefowl juveniles had a higher corticosterone response compared with the White Leghorn. The baseline levels of pregnenolone and DHEA were higher in the Red Junglefowl. Expression levels of 1291 gene transcripts were significantly different between the populations. Gene ontology analysis of differentially expressed genes showed a significant enrichment in ion channel activity. Various GABA receptors, glutamate receptors and transcripts related to potassium and calcium channels were among the genes differentially expressed between the breeds. Stress treatment led to upregulation of 35 transcripts and downregulation of three transcripts. Diminished behavioural and physiological responses in the domesticated chickens was associated with changes in the expression of several genes which are involved in the channel activity pathway. 


\section{Paper III}

\section{Aims and methods}

The aim of this study was to acquire a better understanding of the genes that are involved in the activation and modulation of the HPA axis in the chicken. We investigated transcription of the genes that regulate the HPA axis and the SA system in hippocampus, hypothalamus, pituitary, adrenal glands, and liver in White Leghorn and Red Junglefowl before and after stress. The genes and the tissues were selected based on our prior knowledge of the pathways involved in the regulation of the stress response in each tissue.

\section{Results and conclusion}

The stress affected the expression levels of several genes in the brain, pituitary, and the adrenal glands. In the hypothalamus, the expression levels of EGRI and $C$-FOS increased after the stress treatment. The stress led to downregulation of CRHR1, EGR1 and C-FOS in the pituitary gland. Domestication had affected the expression levels of multiple key stress modulatory genes in the hypothalamus, pituitary, and the adrenal glands. Higher levels of Glucocorticoid receptor $(G R)$ in the hypothalamus of White Leghorn may underlie the cascade of observed differences in the transcription of downstream genes and ultimately explain the hampered HPA axis reactivity in the domesticated chicken. Our results provided important insight into the limited knowledge on the physiological stress response in avian species. 


\section{Paper IV}

\section{Aims and methods}

The aim of this study was to investigate the genetic architecture of the stress response and its modification during domestication. We combined phenotypic QTL mapping with eQTL mapping of the candidate genes in the relevant tissues to search for overlapping genomic regions. The method led to efficient localization of potential candidate genes. As the last step, we looked for correlations between expression levels of the identified genes and hormone levels, which provided a final list of strong candidate genes involved in regulation of stress response.

\section{Results and conclusion}

We found one significant and two suggestive QTL that together explained $20 \%$ of the variance in the corticosterone response. Additionally, two significant QTL for aldosterone on chromosome 2, and one QTL for DHEA on chromosome 5 were detected. Combination of QTL mapping with eQTL mapping led to identification of two candidate genes underlying corticosterone and aldosterone response in chicken. The putative gene underlying the corticosterone QTL was SERPINA10 a member of Serpin A Family with unknown function in chickens. Orthologue DNA regions have been previously associated with corticosterone response in rat and pig. Phosphodiesterase 1C (PDE1C) was identified as the main candidate gene underlying the aldosterone response QTL in our study. Furthermore, in both cases, the gene expression levels were correlated with the plasma levels of the hormones. In conclusion, we identified two strong putative genes underlying domestication-induced modifications of the stress response in chicken. 


\section{Paper V}

Aims and methods

The aim of paper $\mathrm{V}$ was to map genetic loci associated with the transcription levels of genes involved in the physiological stress response. We conducted targeted eQTL analysis in the $F_{12}$ generation of an intercross between White Leghorn and Red Junglefowl. The expression of 46 candidate genes with known functions in the regulation of the HPA axis or the SA system was measured in the hypothalamus and the adrenal glands after a brief stress exposure (physical restraint). We looked at the correlation between gene expression and plasma levels of corticosterone, and assessed the effects of found eQTL on plasma levels of corticosterone. Then, we investigated if a previously reported QTL on chromosome 5 underlying corticosterone response was associated with expressions of the measured genes in hypothalamus and adrenal tissue.

\section{Results and conclusion}

The expression levels of $G R$ in the hypothalamus and several genes in the adrenal glands were correlated with the post-stress levels of corticosterone in plasma. We found several local- and trans-acting eQTL for stress-related genes in both hypothalamus and adrenal glands. In the hypothalamus, one eQTL for $c$-Fos and one for $G R$ were found. In the adrenal tissue, we identified eQTL for several modulators of the stress response. None of the found eQTL were significant predictors of corticosterone levels. The found QTL for corticosterone was associated with the expression of $G R$ in the hypothalamus. The presence of an eQTL for $G R$ in the hypothalamus combined with the negative correlation between $G R$ expression and corticosterone response suggests $G R$ as a candidate for further functional studies regarding modification of the stress response during chicken domestication. 


\section{Discussion}

Animal domestication is associated with the modification of fearfulness and the stress response. This dissertation focused on the genetic architecture of the modified stress response in the domesticated chicken. Similar to other studies that compared domesticated species with their progenitors, we showed that the domesticated chicken has a lowered behavioural and physiological stress response. We attributed the aforementioned differences in the stress response to the modifications in expression levels of stress modulatory genes in the brain, the pituitary, and the adrenal glands. At the next step, we applied quantitative trait mapping to identify genetic loci that modulate gene expression and hormonal response to the acute stress. We identified several quantitative trait loci underlying the expression of stress modulatory genes and the hormonal stress response. At the final step, we combined hormone mapping with gene expression mapping and narrowed two of the hormonal QTL down to the putative causal genes, SERPINA10 and PDEIC. Both of the identified genes were differentially expressed in the adrenal glands of pure White Leghorn and Red Junglefowl and had overlapping eQTL with hormonal QTL. The expression levels of SERPINA10 and PDE1C were correlated with corticosterone and aldosterone levels in plasma.

\section{Effects of domestication on behaviour and physiology}

Mature Red Junglefowl had a more pronounced behavioural and physiological stress response and a shorter recovery period compared with the domesticated White Leghorn. The basal levels of pregnenolone, progesterone, dehydroepiandrosterone (DHEA), and androstenedione, were significantly higher in the White Leghorn, but one hour after restraint stress, due to the significant decrease in the hormone levels in White Leghorns, both breeds had similar hormone levels (Paper I). The suppressive effects of stress on the activity of the hypothalamic-pituitary- 
gonadal (HPG) axis is well studied (reviewed by (Rivier and Rivest, 1991)). Downregulation of EGRI and $C$-FOS in the pituitary glands after the stress (Paper III) may mediate the suppressive action of stress on the HPG axis in chicken. However, the lowered steroid levels after stress might also be influenced by cholesterol depletion in the adrenal glands (Blas, 2015). The natural environments are usually unpredictable and offer constant predation risks. Having a prompt stress response followed by a fast recovery is vital for living in the wild, while in captivity, a strong stress response may be costly and redundant. Selection for production traits and adaptations for tolerating captive environment may have led to the lowered stress response in domesticates (Künzl and Sachser, 1999; Price, 2002; Wilkins et al., 2014). Our Red Junglefowl populations were originally wild caught from Thailand, but they had been maintained in zoos and then in our facility for several generations before the experiments. We can speculate that factors such as unintended selection and genetic drift have been influencing the animals that were used in this dissertation. The studied populations are not intended to represent all domesticated chicken breeds or all populations of Red Junglefowl. However, the lowered stress response due to domestication has been reported in several domesticated species (Treidman and Levine, 1969; Drew et al., 2007; Albert et al., 2008; Trut et al., 2009; Ericsson et al., 2014).

\section{Effects of domestication on gene expression}

We attributed the domestication-induced physiological differences between domesticated White Leghorn and Red Junglefowl (Paper I) to gene expression changes in the brain, pituitary, and adrenal glands (Paper II \& III). For gene expression analysis, we used microarray analysis and RT-PCR. Microarray technology allows simultaneous measurement of expression of thousands of genes, and it has been successfully used to study global expression patterns as well as identification of novel biological pathways (Schulze and Downward, 2001). Microarray analysis in the adrenal glands led to identification of genes which were influenced by the stress or domestication. Functional analysis showed a significant overrepre- 
sentation of genes related to channel activity pathways. Several GABA receptors, glutamate receptors serotonin receptors, and dopamine receptors were among the genes which were differentially expressed between the populations. The enrichment of differentially expressed genes in the pathways that are involved in the biosynthesis of catecholamines suggest an influence of domestication on the activity of SAM in chicken. Due to correction for multiple testing, microarray analysis may fail to find moderate changes in the gene expression, and hence, we used RT-PCR to study expression of the candidate genes that are biologically relevant to the stress response in Paper III. We detected stress and domestication effects on the expression of key stress-related genes (Paper III) that were not detected by microarrays in adrenal glands (Paper II) and hypothalamus (Nätt et al., 2012). White Leghorn had higher expression of $G R$ in the hypothalamus, a lower expression of POMC (precursor of $\mathrm{ACTH})$ in the pituitary gland and lower expression of CYP11A1 and $H S D 3 B 2$ in the adrenal glands. The changes in the expression of the aforementioned genes may partially explain the hampered HPA axis reactivity in domesticated White Leghorn. An interesting question is if independent regulatory elements are responsible for the differences in gene expression within each tissue or if changes in the expression of one gene modulate changes in the expression of others through physiological signalling. In previous studies we showed that stress response is similar between Red Junglefowl and White Leghorn at young ages and the difference between them develops over time (Ericsson and Jensen, 2016, Ericsson, 2014 \#375). We also reported loci that regulate $G R$ expression as well as a negative correlation between $G R$ expression in the hypothalamus and corticosterone levels after stress, however, we did not detect any eQTL for CYP11A1 or HSD3B (Paper V). We suggest that the difference in the expression of steroidogenic genes in the adrenal glands is regulated by the hypothalamus and pituitary gland. Studying the ontogeny of gene expression differences between domesticated chicken and the Red Junglefowl may provide more insights about the mechanisms which regulate gene expression in each tissue.

The effect of acute stress on the pattern of gene expression was in general similar to reported data in mammals (Rivier and Rivest, 1991; Cullinan et al., 
1995). However, we identified some effects that to our knowledge were not previously reported in mammalian species. Rapid increase in $P O M C$ gene expression in the adrenal glands and the decrease in the expression levels of C-FOS in the pituitary glands due to short term stress has been previously reported in mammals to our knowledge.

Although genes provide instruction, proteins are the functional units of almost all biological processes. The assumption of transcription analysis is that mRNA levels and protein levels are highly correlated, but in some cases, the association between mRNA and protein levels has been reported to be small (Bao et al., 2007). Besides protein levels, more than 200 different types of protein modifications that can affect protein activity have been reported in vertebrates (Gygi et al., 1999). Proteomic methods are becoming both more accessible and reliable (Uebbing et al., 2015), and can be used to complement our knowledge about contribution of the molecular pathways that shape phenotypes.

\section{Quantitative trait mapping}

We showed that chicken domestication has affected behaviour, physiology and expression of multiple stress modulatory genes in several tissues (Paper I, II, \& III). The aim of last two papers were to link the gene expression and hormonal defences between the White Leghorn and Red Junglefowl to the potential causal genes or the genomic loci. We identified one significant QTL region for baseline DHEA, and two regions for the stress levels of corticosterone and aldosterone. The confidence interval of each QTL may be large and can contain hundreds or thousands of genes (Darvasi and Soller, 1995). For QTL mapping we used the $12^{\text {th }}$ generation of an intercross between White Leghorn and Red Junglefowl. Intercrossing $F_{2}$ animals for additional generations leads to recombination between any two loci, leading to significant increase in mapping resolution (Darvasi and Soller, 1995).Then we used microarray data from Paper II, and (Nätt et al., 2012) to choose QTL genes for further investigation. Two candidate genes, SERPINA10 for corticosterone and $P D E 1 C$ for aldosterone response, were identified as the poten- 
tial causative genes (Paper IV) Both candidate genes were previously associated with the modulation of the secretory pathway and were functionally relevant to steroidogenesis.

The expression of key steroidogenic genes (CYP11A1 and HSD3B2) were significantly higher in the adrenal glands of Red Junglefowl compared with the domesticated White Leghorn (Paper III). However we did not detect eQTL for either of the above mentioned genes in the adrenal glands of the advanced intercross (Paper IV). It is probable that the difference in the expression of steroidogenic genes in the adrenal glands of pure breed animals is caused by physiological signals (CRH, ACTH) from hypothalamus and pituitary gland rather than direct genetic effects. Absence of significant local eQTL for a majority of measured genes may be attributed to lack of segregation in the founders and the relatively small sample size of our experiment. One shortcoming of using intercrosses for QTL mapping is its limitation to identify only the QTL that segregate within the starting populations and hence this method fails to capture the effects of rare variants (Darvasi and Soller, 1995). Sample size is a critical factor for QTL mapping, and small sample sizes may fail to detect minor effect QTL and overestimate the effect size of the identified QTL (Beavis, 1994). Considering the complexity of the stress response, we can assume that many other QTL with moderate and small effects were not detected due to the low statistical power in our study. QTL studies are inherently correlational and hence do not provide knowledge about the underlying mechanism, but they provide information which can further be used to characterize the impact of allelic variation on gene functions and ultimately phenotype. 


\section{Conclusion}

We studied stress response in the Red Junglefowl, the ancestor of all chicken breeds, and one of its domesticated descendants, White Leghorn. Domestication was associated with a significant decrease in the stress induced levels of corticosterone as well as a lower fearfulness. We showed that domestication process has changed the expression levels of several stress modulatory genes in the brain, pituitary and adrenal glands. Particularly, changes in the expression of $G R$ in the hypothalamus, POMC in the pituitary, and CYP11A1 and HSD3B2, in the adrenal glands may underlie the hampered stress response in the domesticated White Leghorn. As a next step, we used quantitative trait mapping to identify genetic loci that lie behind the found differences in gene expression and hormone levels between the above-mentioned breeds. Several QTL for the domestication related modification of physiological stress response were detected. Combination of QTL and eQTL mapping led to identification of two quantitative trait genes, SERPINA10 and $P D E 1 C$. These genes are candidates for further functional investigation regarding synthesis of corticosterone and aldosterone in the adrenal glands. This dissertation provided insights in physiology and genetics of stress response and its modification during chicken domestication. Our findings expand the basic understanding about the stress response in chicken, which can potentially be used in improving welfare by genetic selection. 


\section{Acknowledgement}

I start by acknowledging my parents for bringing me to the existence and taking good care of me, thank you Mahshid \& Mehdi. Need to thank my sister Maryam for the good times and specially for motivating me for continuing my studies and even filling the LIU admissions and visa forms for me.

Thanks to Per Jensen my supervisor, for always having trust in me (hopefully), for always supporting me, and for always being available. Thank you Dominic and Jordi for guiding and helping me in developing my experiments. Mathias, Hanne, Urban and Jenny, thank you for being a good teacher for me.

My colleagues for tolerating me, and helping me whenever I needed help. Andrey, Fabio, Anna Carin, Bea, Mia, Magnus, Jesper, Rebecca, Petros, Carlos, Ann Charlote, Rie, Enrico, Rubin. Very special thanks to Agneta, Anna, and Eva for their great support and helps.

Johan and Martin (I) for teaching me how to work in the lab, analyse the data and for the nice and sometimes crazy discussions we had. Special thanks to Pia, the smartest girl I have ever been friend with, for proofreading the thesis and for always helping me with everything. To Lejla for being a great friend and help, you made my life a lot easier and happier. Thank you Maria for trying to turn me into a better person as well as the good times we had. Thank you Ann Sofie, the role model of niceness, for translating the popular summary into Swedish.

My super-nice classmates in ethology 2010, Amir, Frida, Alisa, Taina, Joel, Isabella, Andreas, Anser, Nazmul, Anna and Sunghee for the great and fun times we had together during our study.

My great teachers in Iran, Dr. Avesta Sadrzadeh and Dr. Mansour Banani, I need to thank you a lot for being my teacher in life and in academia. Thank you Dr Pourbakhsh for being a great supervisor. My best friends in Iran, Hamed, Alireza, Mohammad, Ali(s) and Amir(s).

Shahrzad, my most hardworking friend ever, for being a great friend and to be an inspiration for me to work harder, you will always have a special place in my mind and memories. To my first and great friend in Linköping Daniel, to my best boyfriend in Sweden Nemo, my best girlfriend ever Svetlana, and to my amazing friend Alba, for the great times we had, I will always remember our interesting talks and drunk nights in Flamman. To my lovely girlfriend Mhaj, for always understanding, supporting, and trying to cheer me up whenever I am too stressed out.

Special thanks to Behzad Shishegaran for designing the super-nice cover of this dissertation!

Linköping in June 2017

Amir Fallahshahroudi 


\section{References}

Abasht, B., Dekkers, J.C.M., Lamont, S.J., 2006. Review of Quantitative Trait Loci Identified in the Chicken. Poult Sci 85, 2079-2096.

Albert, F.W., Kruglyak, L., 2015. The role of regulatory variation in complex traits and disease. Nat Rev Genet 16, 197-212.

Albert, F.W., Shchepina, O., Winter, C., Römpler, H., Teupser, D., Palme, R., Ceglarek, U., Kratzsch, J., Sohr, R., Trut, L.N., 2008. Phenotypic differences in behavior, physiology and neurochemistry between rats selected for tameness and for defensive aggression towards humans. Hormones and Behavior 53, 413-421.

Andersson, L., 2001. Genetic dissection of phenotypic diversity in farm animals. Nature reviews. Genetics 2, 130-138.

Andersson, L., 2012. How selective sweeps in domestic animals provide new insight into biological mechanisms. J. Intern. Med. 271, 1-14.

Andersson, L., Georges, M., 2004. Domestic-animal genomics: deciphering the genetics of complex traits. Nature reviews. Genetics 5, 202-212.

Arnetz, B.B., Ekman, R., 2006. Stress in health and disease. Wiley-VCH.

Axelsson, E., Ratnakumar, A., Arendt, M.-L., Maqbool, K., Webster, M.T., Perloski, M., Liberg, O., Arnemo, J.M., Hedhammar, Å., Lindblad-Toh, K., 2013. The genomic signature of dog domestication reveals adaptation to a starch-rich diet. Nature 495, 360-364.

Bao, L., Peirce, J.L., Zhou, M., Li, H., Goldowitz, D., Williams, R.W., Lu, L., Cui, Y., 2007. An integrative genomics strategy for systematic characterization of genetic loci modulating phenotypes. Hum. Mol. Genet. 16, 1381-1390.

Beavis, W., 1994. The power and deceit of QTL experiments: lessons from comparative QTL studies, Proceedings of the forty-ninth annual corn and sorghum industry research conference, Chicago, IL, pp. 250-266.

Blas, J., 2015. Chapter 33 - Stress in Birds A2 - Scanes, Colin G, Sturkie's Avian Physiology (Sixth Edition), Academic Press, San Diego, pp. 769-810.

Broom, D., 1983. Stereotypies as animal welfare indicators, Indicators relevant to farm animal welfare, Springer, pp. 81-87.

Bucan, M., Abel, T., 2002. The mouse: genetics meets behaviour. Nature reviews. Genetics 3, 114-123.

Buynitsky, T., Mostofsky, D.I., 2009. Restraint stress in biobehavioral research: recent developments. Neurosci. Biobehav. Rev. 33, 1089-1098. 
Cadieu, E., Neff, M.W., Quignon, P., Walsh, K., Chase, K., Parker, H.G., VonHoldt, B.M., Rhue, A., Boyko, A., Byers, A., 2009. Coat variation in the domestic dog is governed by variants in three genes. science 326 , 150-153.

Campler, M., Jöngren, M., Jensen, P., 2009. Fearfulness in red junglefowl and domesticated White Leghorn chickens. Behav Processes 81, 39-43.

Carsia, R.V., 2015. Chapter 26 - Adrenals A2 - Scanes, Colin G, Sturkie's Avian Physiology (Sixth Edition), Academic Press, San Diego, pp. 577-611.

Chrousos, G.P., 2009. Stress and disorders of the stress system. Nature Reviews Endocrinology 5, 374-381.

Clubb, R., Mason, G., 2003. Animal Welfare: Captivity effects on wide-ranging carnivores. Nature 425, 473-474.

Crawford, R.D., 1990. Poultry breeding and genetics. Elsevier Amsterdam.

Cullinan, W.E., Herman, J.P., Battaglia, D.F., Akil, H., Watson, S., 1995. Pattern and time course of immediate early gene expression in rat brain following acute stress. Neuroscience 64, 477-505.

Darnell, J.E., Lodish, H., Baltimore, D., 1990. Molecular cell biology. Scientific American Books New York.

Darvasi, A., Soller, M., 1995. Advanced intercross lines, an experimental population for fine genetic mapping. Genetics 141, 1199-1207.

Darwin, C., 1868. The variation of animals and plants under domestication. O. Judd.

De Kloet, E.R., Joëls, M., Holsboer, F., 2005. Stress and the brain: from adaptation to disease. Nature Reviews Neuroscience 6, 463-475.

Désautés, C., Bidanel, J., Milan, D., Iannuccelli, N., Amigues, Y., Bourgeois, F., Caritez, J., Renard, C., Chevalet, C., Mormede, P., 2002. Genetic linkage mapping of quantitative trait loci for behavioral and neuroendocrine stress response traits in pigs. J Anim Sci 80, 2276-2285.

Diamond, J., 2002. Evolution, consequences and future of plant and animal domestication. Nature 418, 700-707.

Doss, S., Schadt, E.E., Drake, T.A., Lusis, A.J., 2005. Cis-acting expression quantitative trait loci in mice. Genome Res. 15, 681-691.

Drew, R.E., Schwabl, H., Wheeler, P.A., Thorgaard, G.H., 2007. Detection of QTL influencing cortisol levels in rainbow trout (Oncorhynchus mykiss). Aquaculture 272, S183-S194.

Ericsson, M., Fallahsharoudi, A., Bergquist, J., Kushnir, M.M., Jensen, P., 2014. Domestication effects on behavioural and hormonal responses to acute stress in chickens. Physiology \& behavior 133, 161-169. 
Ericsson, M., Jensen, P., 2016. Domestication and ontogeny effects on the stress response in young chickens (Gallus gallus). Scientific Reports 6.

Eriksson, J., Larson, G., Gunnarsson, U., Bed'hom, B., Tixier-Boichard, M., Strömstedt, L., Wright, D., Jungerius, A., Vereijken, A., Randi, E., Jensen, P., Andersson, L., 2008. Identification of the Yellow Skin Gene Reveals a Hybrid Origin of the Domestic Chicken. PLoS Genet 4, e1000010.

Fallahsharoudi, A., de Kock, N., Johnsson, M., Bektic, L., Ubhayasekera, S.J.K.A., Bergquist, J., Wright, D., Jensen, P., 2017. QTL mapping of stress related gene expression in a cross between domesticated chickens and ancestral red junglefowl. Mol Cell Endocrinol 446, 52-58.

Feder, A., Nestler, E.J., Charney, D.S., 2009. Psychobiology and molecular genetics of resilience. Nat Rev Neurosci 10, 446-457.

Flint, J., Mott, R., 2001. Finding the molecular basis of quatitative traits: successes and pitfalls. Nature reviews. Genetics 2, 437-445.

Fumihito, A., Miyake, T., Sumi, S., Takada, M., Ohno, S., Kondo, N., 1994. One subspecies of the red junglefowl (Gallus gallus gallus) suffices as the matriarchic ancestor of all domestic breeds. Proceedings of the National Academy of Sciences 91, 12505-12509.

Gulevich, R., Oskina, I., Shikhevich, S., Fedorova, E., Trut, L., 2004. Effect of selection for behavior on pituitary-adrenal axis and proopiomelanocortin gene expression in silver foxes (Vulpes vulpes). Physiol Behav 82, 513518.

Gygi, S.P., Rochon, Y., Franza, B.R., Aebersold, R., 1999. Correlation between protein and mRNA abundance in yeast. Mol Cell Biol 19, 1720-1730.

Herman, J.P., McKlveen, J.M., Ghosal, S., Kopp, B., Wulsin, A., Makinson, R., Scheimann, J., Myers, B., 2016. Regulation of the Hypothalamic-Pituitary-Adrenocortical Stress Response. Comprehensive Physiology.

Hillier, L.W., Miller, W., Birney, E., Warren, W., Hardison, R.C., Ponting, C.P., Bork, P., Burt, D.W., Groenen, M.A., Delany, M.E., 2004. Sequence and comparative analysis of the chicken genome provide unique perspectives on vertebrate evolution. Nature 432, 695-716.

Hovatta, I., Barlow, C., 2008. Molecular genetics of anxiety in mice and men. Ann Med 40, 92-109.

Jemal, M., 2000. High-throughput quantitative bioanalysis by LC/MS/MS. Biomed. Chromatogr. 14, 422-429.

Jensen, P., 2010. Domestication, selection, behaviour and welfare of animals genetic mechanisms for rapid responses. Animal Welfare 19, 7-9. 
Jensen, P., Andersson, L., 2005. Genomics Meets Ethology: A New Route to Understanding Domestication, Behavior, and Sustainability in Animal Breeding. Ambio 34, 320-324.

Johnsson, M., Williams, M.J., Jensen, P., Wright, D., 2016. Genetical Genomics of Behavior: A novel chicken genomic model for anxiety behavior. Genetics 202, 327-340.

Keeling, L., Andersson, L., Schutz, K.E., Kerje, S., Fredriksson, R., Carlborg, O., Cornwallis, C.K., Pizzari, T., Jensen, P., 2004. Chicken genomics: Feather-pecking and victim pigmentation. Nature 431, 645-646.

Kendziorski, C., Wang, P., 2006. A review of statistical methods for expression quantitative trait loci mapping. Mamm Genome 17, 509-517.

Kerje, S., Carlborg, Ö., Jacobsson, L., Schütz, K., Hartmann, C., Jensen, P., Andersson, L., 2003. The twofold difference in adult size between the red junglefowl and White Leghorn chickens is largely explained by a limited number of QTLs. Anim Genet 34, 264-274.

Koolhaas, J.M., Bartolomucci, A., Buwalda, B., de Boer, S.F., Flügge, G., Korte, S.M., Meerlo, P., Murison, R., Olivier, B., Palanza, P., Richter-Levin, G., Sgoifo, A., Steimer, T., Stiedl, O., van Dijk, G., Wöhr, M., Fuchs, E., 2011. Stress revisited: A critical evaluation of the stress concept. Neuroscience \&amp; Biobehavioral Reviews 35, 1291-1301.

Korte, S.M., Koolhaas, J.M., Wingfield, J.C., McEwen, B.S., 2005. The Darwinian concept of stress: benefits of allostasis and costs of allostatic load and the trade-offs in health and disease. Neurosci. Biobehav. Rev. 29, 3-38.

Kukekova, A.V., Trut, L.N., Chase, K., Kharlamova, A.V., Johnson, J.L., Temnykh, S.V., Oskina, I.N., Gulevich, R.G., Vladimirova, A.V., Klebanov, S., Shepeleva, D.V., Shikhevich, S.G., Acland, G.M., Lark, K.G., 2011. Mapping Loci for fox domestication: deconstruction/reconstruction of a behavioral phenotype. Behavior genetics 41, 593-606.

Künzl, C., Sachser, N., 1999. The behavioral endocrinology of domestication: A comparison between the domestic guinea pig (Cavia aperea f. porcellus) and its wild ancestor, the cavy (Cavia aperea). Hormones and Behavior $35,28-37$.

Lin, D., Sugawara, T., Strauss, J.r., Clark, B.J., Stocco, D.M., Saenger, P., Rogol, A., Miller, W.L., 1995. Role of steroidogenic acute regulatory protein in adrenal and gonadal steroidogenesis. Science 267, 1828-1831.

Mackay, T.F.C., 2001. Quantitative trait loci in Drosophila. Nature reviews. Genetics 2, 11-20.

McEwen, B.S., 2000. Stress, definition and concepts of. Fink, G ed. Academic Press, San Diego. 
McEwen, B.S., Wingfield, J.C., 2003. The concept of allostasis in biology and biomedicine. Hormones and Behavior 43, 2-15.

Moberg, G.P., 2013. Animal stress. Springer.

Mormede, P., Foury, A., Barat, P., Corcuff, J.-B., Terenina, E., Marissal-Arvy, N., Moisan, M.-P., 2011. Molecular genetics of hypothalamic-pituitaryadrenal axis activity and function. Ann N Y Acad Sci 1220, 127-136.

Mormède, P., Foury, A., Terenina, E., Knap, P., 2011. Breeding for robustness: the role of cortisol. animal 5, 651-657.

Mueller, C.A., Burggren, W.W., Tazawa, H., 2015. Chapter 32 - The Physiology of the Avian Embryo A2 - Scanes, Colin G, Sturkie's Avian Physiology (Sixth Edition), Academic Press, San Diego, pp. 739-766.

Necsulea, A., Kaessmann, H., 2014. Evolutionary dynamics of coding and noncoding transcriptomes. Nat Rev Genet 15, 734-748.

Nätt, D., Rubin, C.-J., Wright, D., Johnsson, M., Beltéky, J., Andersson, L., Jensen, P., 2012. Heritable genome-wide variation of gene expression and promoter methylation between wild and domesticated chickens. BMC Genomics 13, 1-12.

Ousova, O., Guyonnet-Duperat, V., Iannuccelli, N., Bidanel, J.-P., Milan, D., Genêt, C., Llamas, B., Yerle, M., Gellin, J., Chardon, P., 2004. Corticosteroid binding globulin: a new target for cortisol-driven obesity. Mol. Endocrinol. 18, 1687-1696.

Paré, W.P., Glavin, G.B., 1986. Restraint stress in biomedical research: a review. Neurosci. Biobehav. Rev. 10, 339-370.

Price, E.O., 1999. Behavioral development in animals undergoing domestication. Applied Animal Behaviour Science 65, 245-271.

Price, E.O., 2002. Animal domestication and behavior. CABI Publishing, Wallingford.

Qureshi, M., Havenstein, G., 1994. A comparison of the immune performance of a 1991 commercial broiler with a 1957 randombred strain when fed “typical" 1957 and 1991 broiler diets. Poult Sci 73, 1805-1812.

Rauw, W.M., Kanis, E., Noordhuizen-Stassen, E.N., Grommers, F.J., 1998. Undesirable side effects of selection for high production efficiency in farm animals: a review. Livestock Production Science 56, 15-33.

Rivier, C., Rivest, S., 1991. Effect of stress on the activity of the hypothalamicpituitary-gonadal axis: peripheral and central mechanisms. Biol Reprod $45,523-532$.

Romero, L.M., Dickens, M.J., Cyr, N.E., 2009. The reactive scope model-a new model integrating homeostasis, allostasis, and stress. Hormones and behavior 55, 375-389. 
Rubin, C.-J., Zody, M.C., Eriksson, J., Meadows, J.R.S., Sherwood, E., Webster, M.T., Jiang, L., Ingman, M., Sharpe, T., Ka, S., 2010. Whole genome resequencing reveals loci under selection during chicken domestication. Nature 464.

Rubin, C.J., Brändström, H., Wright, D., Kerje, S., Gunnarsson, U., Schutz, K., Fredriksson, R., Jensen, P., Andersson, L., Ohlsson, C., 2007. Quantitative trait loci for BMD and bone strength in an intercross between domestic and wildtype chickens. J. Bone Miner. Res. 22, 375384 .

Sapolsky, R.M., Romero, L.M., Munck, A.U., 2000. How Do Glucocorticoids Influence Stress Responses? Integrating Permissive, Suppressive, Stimulatory, and Preparative Actions. Endocr. Rev. 21, 55-89.

Schulze, A., Downward, J., 2001. Navigating gene expression using microarraysa technology review. Nat Cell Biol 3, E190-E195.

Schütz, K., Kerje, S., Carlborg, Ö., Jacobsson, L., Andersson, L., Jensen, P., 2002a. QTL analysis of a red junglefowl $x$ White Leghorn intercross reveals trade-off in resource allocation between behaviour and production traits. Behav Genet 32.

Schütz, K., Kerje, S., Carlborg, Ö., Jacobsson, L., Andersson, L., Jensen, P., 2002b. QTL analysis of a red junglefowl $\times$ White Leghorn intercross reveals trade-off in resource allocation between behavior and production traits. Behav Genet 32, 423-433.

Schütz, K., Kerje, S., Jacobsson, L., Forkman, B., Carlborg, Ö., Andersson, L., Jensen, P., 2004. Major Growth QTLs in Fowl Are Related to Fearful Behavior: Possible Genetic Links Between Fear Responses and Production Traits in a Red Junglefowl $\times$ White Leghorn Intercross. Behavior genetics 34, 121-130.

Schütz, K.E., Forkman, B., Jensen, P., 2001. Domestication effects on foraging strategy, social behaviour and different fear responses: a comparison between the red junglefowl (Gallus gallus) and a modern layer strain. Applied animal behaviour science 74, 1-14.

Selye, H., 1973. The Evolution of the Stress Concept: The originator of the concept traces its development from the discovery in 1936 of the alarm reaction to modern therapeutic applications of syntoxic and catatoxic hormones. Am Sci 61, 692-699.

Shearin, A.L., Ostrander, E.A., 2010. Canine morphology: hunting for genes and tracking mutations. PLoS Biol 8, e1000310.

Solberg, L.C., Baum, A.E., Ahmadiyeh, N., Shimomura, K., Li, R., Turek, F.W., Takahashi, J.S., Churchill, G.A., Redei, E.E., 2006. Genetic analysis of the stress-responsive adrenocortical axis. Physiol. Genomics 27, 362369. 
Soleimani, A.F., Zulkifli, I., Omar, A.R., Raha, A.R., 2011. Physiological responses of 3 chicken breeds to acute heat stress. Poult Sci 90, 14351440.

Stocco, D.M., 2001. StAR protein and the regulation of steroid hormone biosynthesis. Annu Rev Physiol 63, 193-213.

Tixier-Boichard, M., Bed'hom, B., Rognon, X., 2011. Chicken domestication: From archeology to genomics, CR Biologies.

Treidman, D.M., Levine, S., 1969. Plasma corticosteroid response to stress in four species of wild mice. Endocrinology 84, 676-680.

Trut, L., Oskina, I., Kharlamova, A., 2009. Animal evolution during domestication: the domesticated fox as a model. BioEssays : news and reviews in molecular, cellular and developmental biology 31, 349-360.

Uebbing, S., Konzer, A., Xu, L., Backström, N., Brunström, B., Bergquist, J., Ellegren, H., 2015. Quantitative mass spectrometry reveals partial translational regulation for dosage compensation in chicken. Molecular biology and evolution, msv147.

Wilkins, A.S., Wrangham, R.W., Fitch, W.T., 2014. The "domestication syndrome" in mammals: a unified explanation based on neural crest cell behavior and genetics. Genetics 197, 795-808.

Wingfield, J., Sapolsky, R., 2003. Reproduction and resistance to stress: when and how. J Neuroendocrinol 15, 711-724.

Wray, G.A., 2007. The evolutionary significance of cis-regulatory mutations. Nat Rev Genet 8, 206-216.

Wright, D., Rubin, C., Schutz, K., Kerje, S., Kindmark, A., Brandstrom, H., Andersson, L., Pizzari, T., Jensen, P., 2012a. Onset of sexual maturity in female chickens is genetically linked to loci associated with fecundity and a sexual ornament. Reproduction in domestic animals = Zuchthygiene 47 Suppl 1, 31-36.

Wright, D., Rubin, C., Schutz, K., Kerje, S., Kindmark, A., Brandström, H., Andersson, L., Pizzari, T., Jensen, P., 2012b. Onset of Sexual Maturity in Female Chickens is Genetically Linked to Loci Associated with Fecundity and a Sexual Ornament. Reproduction in Domestic Animals 47, 31-36.

Wright, D., Rubin, C.J., Martinez Barrio, A., SchÜTz, K., Kerje, S., BrÄNdstrÖM, H., Kindmark, A., Jensen, P., Andersson, L., 2010. The genetic architecture of domestication in the chicken: effects of pleiotropy and linkage. Molecular ecology 19, 5140-5156.

Xiang, H., Gao, J., Yu, B., Zhou, H., Cai, D., Zhang, Y., Chen, X., Wang, X., Hofreiter, M., Zhao, X., 2014. Early Holocene chicken domestication in northern China. Proceedings of the National Academy of Sciences. 
Xing, Y., Parker, C.R., Edwards, M., Rainey, W.E., 2010. ACTH is a potent regulator of gene expression in human adrenal cells. J Mol Endocrinol $45,59-68$.

Yalcin, B., Willis-Owen, S.A., Fullerton, J., Meesaq, A., Deacon, R.M., Rawlins, J.N., Copley, R.R., Morris, A.P., Flint, J., Mott, R., 2004. Genetic dissection of a behavioral quantitative trait locus shows that Rgs2 modulates anxiety in mice. Nature genetics 36, 1197-1202. 



\section{Publications}

The articles associated with this thesis have been removed for copyright reasons. For more details about these see:

http://urn.kb.se/resolve?urn=urn:nbn:se:liu:diva-137350 